\title{
PENGEMBANGAN LEMBAR KERJA PESERTA DIDIK MENGGUNAKAN SOFTWARE GEOGEBRA PADA MATERI TRANSFORMASI GEOMETRI
}

\author{
Mariyanti Elvi $^{*}$ iD , Nur Asma Riani Siregar² ${ }^{(D)}$, Susanti Susanti ${ }^{3}$ \\ Universitas Maritim Raja Ali Haji, Indonesia \\ 1*mariyantielvi@umrah.ac.id, 2nur asmariani@umrah.ac.id, 3shanty@umrah.ac.id
}

Received: April 14, 2021

Revised: May 4, 2021

Accepted: May 17, 2021

\begin{abstract}
:
Geometry is a mathematical science that studied points, lines, planes, spaces, and the relationships of them. One of the topic is geometric transformation. The Several research found that students hadn't understood the concept of transformation, so that it needed a teaching material especially student's worksheet. The research aimed to develop valid, practical and effective student's worksheet with GeoGebra on the geometry transformation in junior high school. The research method was used R\&D (Research and Development) using a modification of the 4-D model. The development model consists defined, designed and developed. The results of the research indicated that (1) this product was valid according to media experts and material experts, (2) it was practical, (3) effective to be used in mathematics learning, especially geometric transformation.
\end{abstract}

Keywords: geometric transformation, GeoGebra, student worksheet.

How to Cite: Elvi, M., Siregar, N. A. R., \& Susanti, S.. (2021). Pengembangan Lembar Kerja Peserta Didik Menggunakan Software GeoGebra pada Materi Transformasi Geometri. Alifmatika: Jurnal $\begin{array}{llll}\text { Pendidikan dan Pembelajaran } & \text { 80-91 }\end{array}$ https://doi.org/10.35316/alifmatika.2021.v3i1.80-91

\section{PENDAHULUAN}

Matematika merupakan suatu kajian ilmu yang berperan penting dalam bidang pendidikan dan menghasilkan sumber daya manusia yang kompeten. Matematika adalah mata pelajaran wajib yang telah diajarkan sejak jenjang Sekolah Dasar (SD) sampai jenjang Sekolah Menengah Atas (SMA). Matematika diajarkan dengan maksud membekali peseta didik untuk memiliki kemampuan berpikir logis, analitis, sistematis, kritis dan kreatif serta kemampuan bekerja sama (Prabawati, Herman, \& Turmudi, 2019). Menurut NCTM (Nasional Council Teachers of Mathematics) pembelajaran matematika sekolah melibatkan lima standar isi yaitu konsep dan operasi bilangan, pengukuran geometri, aljabar serta analisis data dan peluang (Supriyadi, Suharto, \& Hobri, 2017).

Geometri merupakan ilmu matematika yang mempelajari titik, garis, bidang dan ruang serta hubungan diantaranya (Nur'aini, Harahap, Badruzzaman, \& Darmawan, 2017). Melalui geometri, peserta didik akan belajar berbagai bentuk, struktur, karakteristik dan hubungan antar objek geometri. Geometri melibatkan proses kognitif visualisasi dan penalaran yang merupakan keterampilan esensial dalam belajar matematika (Gunhan, 2014). Geometri dipelajari pada setiap jenjang pendidikan yang dibagi menjadi beberapa pokok bahasan. Salah satu pokok 
bahasan geometri pada jenjang Sekolah Menengah Pertama (SMP) adalah transformasi geometri. Transformasi geometri SMP mempelajari tentang translasi (pergeseran), refleksi (pencerminan), rotasi (perputaran), dan dilatasi (perkalian).

Berdasarkan hasil wawancara dengan guru dan peserta didik diperoleh informasi bahwa peserta didik belum bisa menggambar bayangan objek hasil transformasi. Hal ini sejalan dengan beberapa penelitian yang mengungkapkan bahwa peserta didik kesulitan memahami konsep dalam mengidentifikasi transformasi seperti bagaimana merefleksikan suatu bangun, melakukan rotasi pada bangun yang lebih kompleks, serta menerapkan prosedur atau langkahlangkah untuk menyelesaikan soal-soal transformasi geometri (Albab, Hartono, \& Darmawijoyo, 2014; Haqq, Nur'azizah, \& Toheri, 2019). Sejalan dengan itu, NagyKondor (2010) menemukan bahwa peserta didik kesulitan dalam memanipulasi objek geometri diantaranya melakukan rotasi suatu bangun. Selain itu peserta didik juga masih kesulitan dalam menvisualisasikan objek hasil transformasi (Bansilal \& Naidoo, 2012). Untuk mengatasi kesulitan tersebut, perlu adanya pengembangan dalam pembelajaran matematika baik dari segi strategi pembelajaran dikelas maupun perangkat pembelajaran seperti media dan bahan pembelajaran (Fitriyah, Santoso, \& Suryadinata, 2018).

Bahan pembelajaran atau bahan ajar merupakan seperangkat materi pembelajaran yang disusun secara sistematis memuat semua kompetensi dasar yang harus dimiliki oleh peserta didik. Bahan ajar disusun untuk mencapai suatu tujuan pembelajaran dan dapat digunakan oleh peserta didik dalam proses belajar mengajar (Al-Tabany, 2017). Penggunaan bahan ajar membantu peserta didik aktif dalam menyelesaikan masalah, serta membantu guru untuk membuat pembelajaran yang menarik dan menyenangkan (Destino, Bharata, \& Caswita, 2019). Berdasarkan hasil wawancara, guru masih kesulitan dalam membuat alternatif bahan ajar yang mampu meningkatkan minat belajar siswa.

Bahan ajar dapat dikelompokkan beberapa jenis bahan ajar yaitu buku, handout, lembar kerja siswa/peserta didik dan modul (Al-Tabany, 2017). Lembar Kerja Peserta Didik (LKPD) merupakan salah satu bahan ajar yang dapat mengatasi kesulitan dan mendukung keberhasilan peserta didik dalam pembelajaran matematika. LKPD adalah lembar-lembaran tugas yang harus dikerjakan oleh peserta didik. Pada LKPD terdapat petunjuk dan langkah-langkah dalam menyelesaikan tugas tersebut. LKPD juga berisikan bimbingan guru dalam pembelajaran yang disajikan secara menarik dengan beberapa media grafis untuk menarik minat belajar peserta didik (Handayani \& Mandasari, 2018).

LKPD sebagai bahan ajar berfungsi : (1) produk yang dapat mengganti peran guru, (2) peserta didik lebih mudah memahami materi pembelajaran, (3) membuat peserta didik lebih aktif, dan (4) sebagai hasil atau produk yang dapat digunakan dalam berlatih (Gitriani, Aisah, Hendriana, \& Herdiman, 2018). Tujuan penggunaan LKPD adalah untuk meningkatkan aktivitas peserta didik, meningkatkan pemahaman sehingga dapat mengoptimalkan tujuan pembelajaran (Fitri, Noviana, \& Fendrik, 2017). Penggunaan LKPD diharapkan dapat membantu peserta didik dalam proses pembelajaran dan mengatasi kesulitan siswa memahami materi ajar.

Pada kurikulum 2013 penggunaan teknologi sangat dianjurkan. Pembelajaran dengan memanfaatkan teknologi dapat meningkatkan efisiensi dan efektivitas pembelajaran. Melalui penggunaan teknologi, peserta didik dapat 
mempelajari keseluruhan objek matematika yang abstrak. Salah satu penggunaan teknologi dalam pembelajaran matematika adalah penggunaan software GeoGebra. GeoGebra dikembangkan oleh Markus Hohenwarter pada tahun 2001. GeoGebra adalah program komputer (software) untuk mengajarkan matematika. GeoGebra menggabungkan beberapa cabang ilmu matematika diantaranya geometri, aljabar, statistik dan kalkulus (Hohenwarter, Hohenwarter, Kreis, \& Lavicza, 2008). GeoGebra merupakan suatu sistem geometri yang dapat melukis titik, segmen garis, vector dan grafik fungsi. GeoGebra sangat mudah dioperasikan dan dapat digunakan untuk pembelajaran matematika sekolah maupun perguruan tinggi (Sangwin, 2007).

GeoGebra berfungsi sebagai media pembelajaran yang memberikan tampilan visual kepada peserta didik sehingga peserta didik dapat berinteraksi dengan konsep geometri. Selain itu peserta didik dapat memanipulasi berbagai objek geometri yang diharapkan dapat menarik minat, kreatifitas dan efektivitas dalam belajar (Asngari, 2015). Software GeoGebra menawarkan fitur yang dapat mentransformasikan objek geometri. Peserta didik dapat membuat bangun dengan mudah, mengukur jarak, sudut dan luas dengan tepat, serta menyusun dan mengurai objek yang membutuhkan visualisasi seperti translasi, refleksi, rotasi dan dilatasi (Hanafi, Wulandari, \& Wulansari, 2017).

Beberapa penelitian sebelumnya sudah mengembangkan LKPD dengan bantuan GeoGebra pada berbagai materi seperti bangun ruang sisi datar, trigonometri dan turunan (Asngari, 2015; Fatimah, Amam, \& Effendi, 2017; Haji \& Herawaty, 2019). Pada penelitian ini penulis mengembangkan bahan ajar berbentuk LKPD dengan menggunakan software GeoGebra pada materi transformasi geometri untuk SMP. Tujuan dari penelitian ini adalah untuk mengembangkan lembar kerja peserta didik yang valid, praktis dan efektif.

\section{METODE PENELITIAN}

Penelitian ini merupakan penelitian pengembangan, model pengembangan yang digunakan adalah model 4-D. Model ini dikembangkan oleh Thiagarajan, Semmel dan Semmel pada tahun 1974 (Al-Tabany, 2017). Model ini terdiri dari 4 tahap pengembangan yaitu define (pendefinisian), design (perancangan), develop (pengembangan), disseminate (pendiseminasian). Namun, peneliti hanya menerapkan 3 tahap pengembangan saja yaitu define, design, dan develop. Hal ini karena penerapan LKPD ini harus disesuaikan dengan materi yang diajarkan di sekolah, selain itu penerapannya membutuhkan waktu cukup lama.

1. Define (Tahap pendefinisian)

Tahap ini bertujuan untuk menentukan dan menetapkan syarat-syarat pembelajaran. Kegiatan pada tahap ini meliputi (a) analisis awal, (b) analisis peserta didik, (c) analisis tugas, (d) analisis konsep, dan (e) perumusan tujuan pembelajaran (Octariani \& Rambe, 2018).

2. Design (Tahap perancangan)

Tahap ini bertujuan untuk menyiapkan prototype perangkat pembelajaran. Tahap ini terdiri dari beberapa langkah, yakni:

a. Penyusunan tes acuan patokan, peneliti menyusun intrument validasi untuk menguji kelayakan LKPD yang dikembangkan 
b. Pemilihan media yang sesuai dengan kebutuhan peserta didik, menyiapkan referensi

c. Pemilihan format, pada kegiatan ini peneliti menyusun design modul yang sesuai dengan kebutuhan peserta didik.

3. Develop (Tahap pengembangan)

Tahap ini bertujuan untuk menghasilkan LKPD yang sudah direvisi sesuai masukan para ahli yaitu ahli materi dan ahli media. Tahap ini meliputi kegiatan ;

a. Validasi ahli, LKPD yang dikembangkan diuji kelayakannya oleh para ahli. Validasi dilakukan oleh 2 orang ahli yaitu validasi ahli materi dan validasi ahli media. Ahli materi akan menilai LKPD ini dari aspek ketepatan materi dan kesesuai materi dengan tingkat berpikir peserta didik, sedangkan ahli media menilai LKPD ini dari aspek format, desain, dan kemenarikan tampilan LKPD bagi peserta didik. Masukan dan saran dari pada ahli digunakan untuk memperbaiki LKPD.

b. Ui coba LKPD, tahap ini peneliti melakukan uji coba LKPD kepada 15 orang peserta didik kelas VIII SMP dengan tujuan mengetahui kepraktisan LKPD ini untuk digunakan secara luas

c. Revisi, dilakukan berdasarkan evaluasi dan masukan dari peserta didik pada kegiatan uji coba

d. Produk akhir LKPD siap untuk digunakan. 
Adapun alur penelitian pengembangan ini dapat dilihat pada bagan berikut.

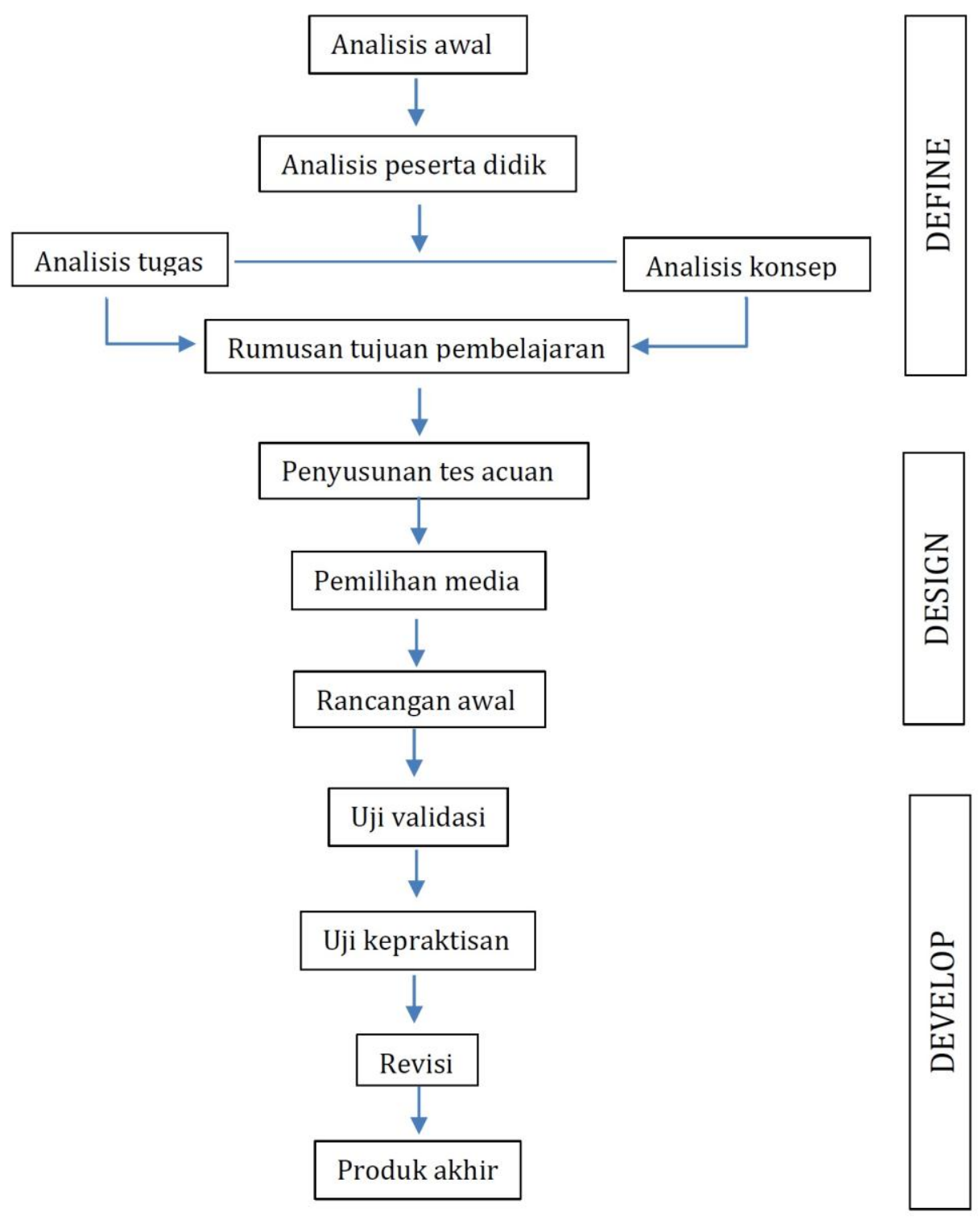

Gambar 1. Bagan pengembangan LKPD

Produk yang dikembangkan adalah LKPD berbantuan software GeoGebra pada materi transformasi geometri. Teknik pengumpulan data yang digunakan adalah wawacara, angket dan tes. Wawancara dilakukan pada tahap awal dengan tujuan untuk mengetahui kendala guru matematika kelas VIII dalam membuat alternatif bahan ajar. Sedangkan instrument penelitian yang digunakan adalah angket validasi ahli, angket respon peserta didik dan tes yang berbentuk uraian. Teknik analisis data meliputi analisis validitas produk, analisis kepraktisan produk dan analisis keefektifan. Analisis validitas produk dilakukan oleh validator yang mencakup aspek ketepatan isi, kemenarikan isi, desain LKPD, dan kualitas keseluruhan. Tabel 1 berikut merupakan kriteria penilaian validasi oleh ahli. 
Tabel 1. Kriteria penilaian validasi ahli

\begin{tabular}{ll}
\hline \multicolumn{1}{c}{ Interval } & \multicolumn{1}{c}{ Kriteria penilaian } \\
\hline $81 \leq x \leq 100$ & Sangat layak \\
$61 \leq x<81$ & Layak \\
$41 \leq x<61$ & Cukup layak \\
$21 \leq x<41$ & Tidak layak \\
$0 \leq x<21$ & Sangat tidak layak \\
\hline
\end{tabular}

(Septina, Farida, \& Komarudin, 2018)

Analisis kepraktisan produk dilakukan oleh peserta didik yang mencakup aspek penyajian materi, tampilan LKPD, dan kebermanfaatan LKPD dalam pembelajaran. Berikut tabel kriteria penilaian respon peserta didik

Tabel 2. Kriteria penilaian peserta didik

\begin{tabular}{ll}
\hline \multicolumn{1}{c}{ Interval } & \multicolumn{1}{c}{ Kriteria penilaian } \\
\hline $81 \leq x \leq 100$ & Sangat praktis \\
$61 \leq x<81$ & Praktis \\
$41 \leq x<61$ & Cukup praktis \\
$21 \leq x<41$ & Tidak praktis \\
$0 \leq x<21$ & Sangat tidak praktis \\
\hline
\end{tabular}

(Septina et al., 2018)

Keefektifan produk yang dikembangkan diukur dengan tercapainya tujuan pembelajaran. LKPD dikatakan efektif jika 80\% peserta didik memperoleh nilai diatas KKM (Asngari, 2015). Nilai KKM yang ditetapkan adalah 72.

\section{HASIL DAN PEMBAHASAN}

Pengembangan LKPD berbantuan software GeoGebra pada materi transformasi geometri SMP melalui beberapa tahapan yaitu define, design, dan develop.

1. Tahap Define

Pada tahap ini peneliti melakukan wawancara dengan guru dan peserta didik. Hal ini dilakukan untuk mengetahui: (1) masalah yang dihadapi guru dalam menentukan alternative bahan ajar yang akan digunakan dalam pembelajaran, (2) mengetahui kebutuhan peserta didik akan suatu bahan ajar sehingga menimbulkan semangat dan minat dalam belajar. serta (3) untuk mengetahui kemampuan peserta didik dalam menggunakan teknologi dalam pembelajaran. 
Berdasarkan hasil wawancara, peneliti menentukan materi yang cocok untuk dipadukan dengan teknologi, sehingga bantuan teknologi semakin memudahkan peserta didik dalam memahami materi pembelajaran. Materi yang cocok dengan kondisi tersebut adalah materi transformasi geometri.

2. Tahap Design

Pada tahap ini, peneliti menyiapkan (a) referensi yang berkenaan dengan materi transformasi geometri dan software GeoGebra seperti buku ajar matematika SMP kelas VII, Modul Transformasi geometri dan panduan GeoGebra, (b) memilih format atau desain yang menarik bagi peserta didik, seperti format huruf, design gambar dan tata letak.

3. Tahap Develop

Pada tahap ini LKPD yang sudah dirancang, divalidasi oleh 2 orang validator yang terdiri dari ahli materi dan ahli media. Hal ini bertujuan memperoleh saran dari validator sehingga LKPD yang dikembangkan benar-benar layak untuk digunakan. Hasil validasi LKPD oleh para ahli dapat dilihat pada tabel berikut :

Tabel 3. Hasil Analisis Validasi

\begin{tabular}{cc}
\hline Aspek Penilaian & Penilaian ahli \\
\hline Ketepatan isi & 85 \\
Kemenarikan isi & 76 \\
Design LKPD & 78 \\
Kualitas keseluruhan & 80 \\
\hline Rata-rata & 79,75 \\
\hline
\end{tabular}

Berdasarkan tabel diatas diperoleh bahwa hasil validasi LKPD oleh validator adalah 79,75 sehingga LKPD ini dinilai layak untuk diujicobakan. Berdasarkan hasil review produk, secara keseluruhan produk LKPD ini sudah cukup baik. Namun ada beberapa bagian yang harus diperbaiki diantaranya pada bagian desain cover dan penggunaan aplikasi GeoGebra.

Tabel 4. Revisi LKPD Berdasarkan Hasil Review

\begin{tabular}{lll}
\hline \multirow{2}{*}{ Aspek } & \multicolumn{1}{c}{ Sebelum } & \multicolumn{1}{c}{ Revisi } \\
\cline { 2 - 3 } Cover LKPD & $\begin{array}{l}\text { Cover LKPD terlihat sederhana } \\
\text { dengan warna yang mencolok }\end{array}$ & $\begin{array}{l}\text { Cover didesain menjadi lebih } \\
\text { menarik dengan warna yang } \\
\text { serasi }\end{array}$ \\
$\begin{array}{lll}\text { Penggunaan } \\
\text { GeoGebra } \\
\text { pada LKPD }\end{array}$ & $\begin{array}{l}\text { Tidak ada panduan dalam } \\
\text { mengoperasikan software }\end{array}$ & $\begin{array}{l}\text { Diberikan panduan dalam } \\
\text { menggambar objek geometri } \\
\text { dan melakukan transfoemasi }\end{array}$ \\
\hline
\end{tabular}




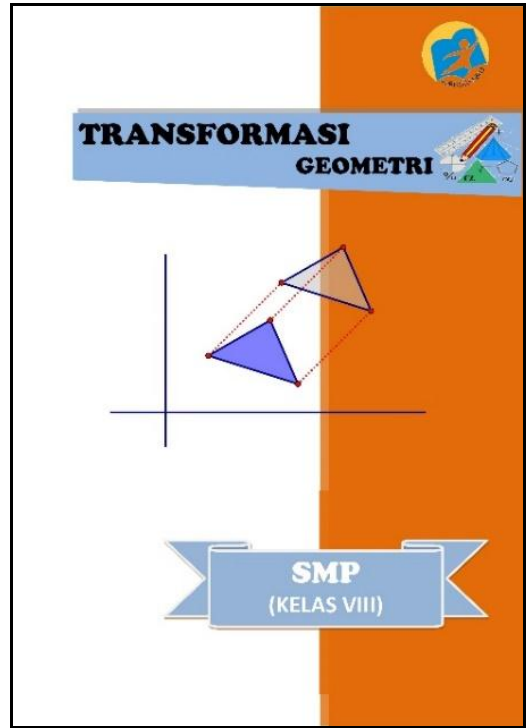

Sebelum revisi

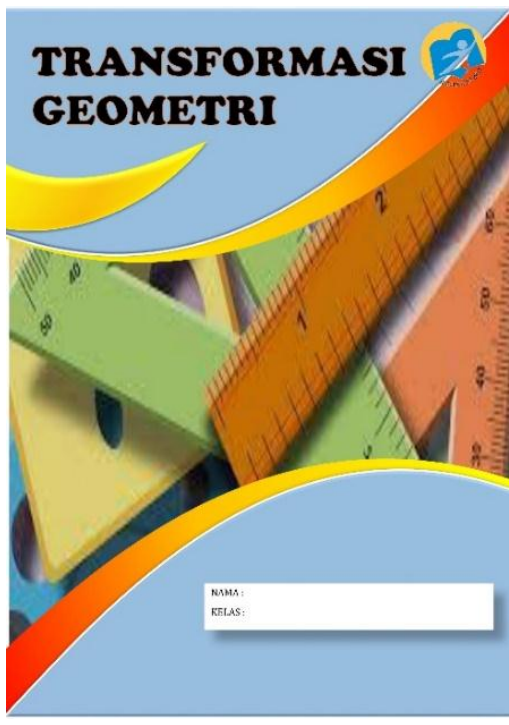

Sesudah revisi

Gambar 2. Cover LKPD

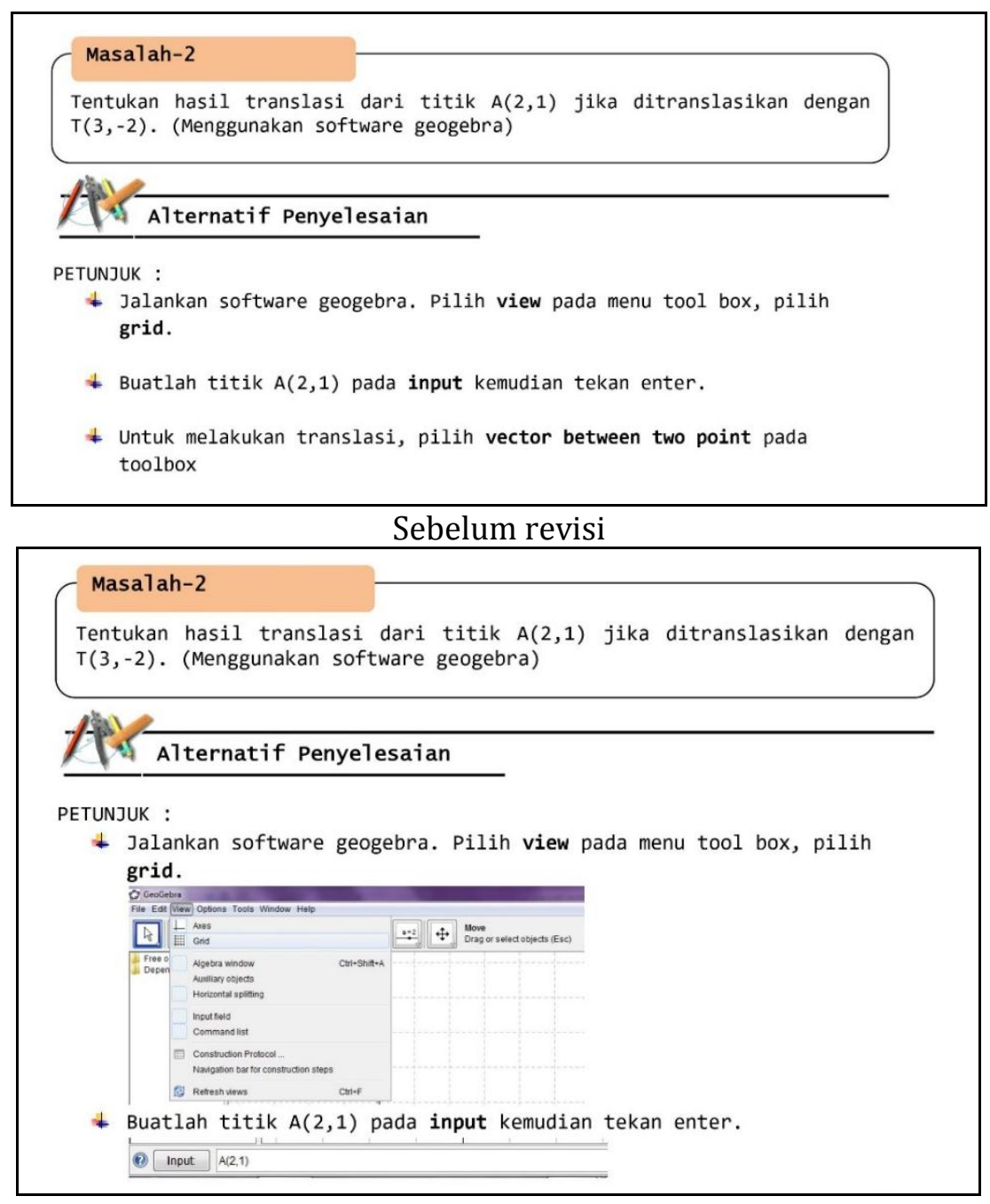

Sesudah revisi

Gambar 3. Panduan penggunaan GeoGebra pada LKPD 
Selanjutnya peneliti melakukan ujicoba LKPD hasil revisi kepada peserta didik kelas VIII SMP. Ujicoba ini bertujuan untuk mengetahui respon peserta didik terhadap kepraktisan penggunaan LKPD ini. Peserta didik yang dipilih sebanyak 15 orang dengan kemampuan matematis yaitu tinggi, sedang, dan rendah. Pada pelaksanaannya peserta didik diberikan angket respon dan tes tentang materi transformasi geometri. Tes diberikan dengan tujuan untuk melihat keefektifan penggunaan LKPD dalam pembelajaran. Hasil angket respon peserta didik dapat dilihat pada tabel berikut :

Tabel 4. Hasil analisis kepraktisan oleh peserta didik

\begin{tabular}{cc}
\hline Aspek Penilaian & Hasil Validasi \\
\hline Penyajian materi & 84 \\
Tampilan LKPD & 80 \\
Kebermanfaatan LKPD & 82 \\
\hline Rata-rata & 82 \\
\hline
\end{tabular}

Hasil penilaian peserta didik terhadap LKPD yaitu 82 dengan kriteria sangat praktis, sehingga LKPD sangat praktis untuk digunakan oleh peserta didik dalam pembelajaran. Penggunaan LKPD dalam pembelajaran memberikan dampak yang baik bagi peserta didik, hal ini terlihat dari hasil tes yang diberikan peneliti untuk menguji keefektifan LKPD.

Tabel 5. Hasil sintak pembelajaran menggunakan LKPD

\begin{tabular}{ccc}
\hline Rata-Rata Nilai Tes & Lulus KKM & $\begin{array}{c}\text { Persentase Lulus KKM } \\
\text { KKM }\end{array}$ \\
\hline 81,7 & 13 orang & $86,67 \%$ \\
\hline
\end{tabular}

Berdasarkan Tabel 5, diketahui bahwa rata-rata nilai peserta didik adalah 81,7 yang tergolong baik menurut kriteria nilai sekolah. Hasil tes materi transformasi geometri menunjukkan bahwa 13 orang peserta didik memperoleh nilai diatas 72 artinya ada $86,67 \%$ peserta didik mencapai KKM. Berdasarkan kriteria yang telah ditetapkan, bahwa LKPD dikatakan efektif jika lebih $80 \%$ dari peserta didik yang diujikan memperoleh nilai diatas KKM. Jadi, dari hasil tes diketahui bahwa LKPD ini sangat efektif untuk digunakan sebagai bahan ajar dalam pembelajaran matematika dengan materi transformasi geometri. Hasil uji validasi, angket respon peserta didik dan hasil tes, menunjukkan bahwa LKPD ini layak, praktis, dan efektif untuk digunakan oleh peserta didik.

LKPD disusun berdasarkan tahapan pembelajaran pemberian masalah, mengidentifikasi masalah, merumuskan gagasan dan kesimpulan. Langkahlangkah ini membantu peserta didik dalam menemukan konsep dari transformasi geometri sehingga dapat meningkatkan pemahaman dan kreativitas dalam mengkontruksi pengetahuan baru. Selain itu peserta didik juga lebih aktif dalam proses pembelajaran. Sejalan dengan Fitri et al. (2017) yang mengemukakan 
bahwa pembelajaran dengan LKPD membuat peserta didik tidak merasa jenuh dan bersemangat dalam menyelesaikan masalah yang terdapat pada LKPD. Fitriyah (2018) juga menjelaskan bahwa penggunaan LKPD mengarahkan peserta didik untuk menemukan konsep-konsep translasi, refleksi, rotasi dan dilatasi.

LKPD dengan bantuan software GeoGebra, memberikan kesempatan kepada peserta didik untuk mengembangkan daya visualisasinya melalui sajian yang terdapat pada program GeoGebra. Program GeoGebra memberikan siswa kemudahan dalam mengeksplorasi kemampuan visualisasinya dengan menggeser, merefleksikan, memutar serta memperbesar atau memperkecil objek. Hanafi et al. (2017) dalam penelitiannya menyebutkan bahwa program GeoGebra menampilkan visualisasi sederhana dari beberapa konsep geomeri. Adanya fiturfitur visualisasi dalam GeoGebra sangat efektif dalam membantu peserta didik memahami konsep geometri khususnya transformasi geometri. Selain itu, menurut Asngari (2015) pembelajaran berbantuan GeoGebra sangat efektif dalam pembelajaran geometri. Software GeoGebra menyajikan visualisasi yang menarik, sehingga memberikan kesempatan kepada siswa untuk melakukan observasi dan eksplorasi dalam mempelajari konsep (Herawati, 2017; Mawarsari \& Purnomo, 2017; Rohaeti \& Bernard, 2018). Jadi penggunaan lembar kerja peserta didik dengan bantuan GeoGebra dapat mengembangkan daya visual peserta didik sehingga mampu mengkontruksi pemahaman tentang transformasi geometri sendiri.

\section{KESIMPULAN DAN SARAN}

Berdasarkan hasil dan pembahasan mengenai pengembangan LKPD berbantuan GeoGebra pada materi transformasi geometri SMP dapat disimpulkan bahwa LKPD ini dapat digunakan sebagai alternative bahan ajar. LKPD ini sudah memenuhi kriteria valid, praktis dan efektif. Validasi LKPD ini lakukan oleh ahli media dan ahli materi. Hasil validasi menunjukkan bahwa LKPD ini layak untuk digunakan. Selanjutnya, hasil uji coba kepada peserta didik menunjukkan bahwa LKPD ini sangat praktis, sedangkan hasil tes menunjukkan bahwa LKPD ini efektif digunakan dalam pembelajaran. Berdasarkan kesimpulan tersebut, ada beberapa saran yang dapat peneliti rekomendasikan yaitu 1) LKPD ini diharapkan dapat digunakan sebagai alternative bahan ajar bagi peserta didik; dan 2) LKPD ini dijadikan acuan dalam mengembangkan LKPD matematika pada materi lain.

\section{DAFTAR PUSTAKA}

Al-Tabany, T. I. B. (2017). Mendesain Model Pembelajaran Inovatif, Progresif, Dan Konteksual. Prenada Media.

Albab, I. U., Hartono, Y., \& Darmawijoyo, D. (2014). Kemajuan Belajar Siswa Pada Geometri Transformasi Menggunakan Aktivitas Refleksi Geometri. Jurnal Cakrawala Pendidikan, 3(3), 338-348. https://doi.org/10.21831/cp.v3i3.2378

Asngari, D. R. (2015). Penggunaan Geogebra dalam Pembelajaran Geometri. Seminar Nasional Matematika Dan Pendidikan Matematika UNY, 299-302. 
Bansilal, S., \& Naidoo, J. (2012). Learners engaging with transformation geometry. South African Journal of Education, 32(1), 26-39. https://doi.org/10.15700/saje.v32n1a452

Destino, M. D., Bharata, H., \& Caswita, C. (2019). Pengembangan Bahan Ajar Transformasi Geometri Berorientasi pada Kemampuan Bepikir Kritis Peserta Didik. Kreano, Jurnal Matematika Kreatif-Inovatif, 10(1), 57-67. https://doi.org/10.15294/kreano.v10i1.18493

Fatimah, A. T., Amam, A., \& Effendi, A. (2017). Konstruksi Pengetahuan Trigonometri Kelas X Melalui Geogebra dan LKPD. JNPM (Jurnal Nasional Pendidikan Matematika), 1(2), 178. https://doi.org/10.33603/jnpm.v1i2.596

Fitri, R. A., Noviana, E., \& Fendrik, M. (2017). Pengembangan lembar kerja siswa (LKS) pada mata pelajaran matematika kelas 5 sekolah dasar (penelitian pengembangan dengan materi volume kubus dan balok Di SD IT Al-Fityah). Jurnal Online Mahasiswa Fakultas Keguruan Dan Ilmu Pendidikan Universitas Riau, 4(1), 1-12.

Fitriyah, D. N., Santoso, H., \& Suryadinata, N. (2018). Bahan Ajar Transformasi Geometri Berbasis Discovery Learning melalui Pendekatan Etnomatematika. 4(2), 145-158. https://doi.org/10.29408/jel.v4i2.705

Gitriani, R., Aisah, S., Hendriana, H., \& Herdiman, I. (2018). Pengembangan Lembar Kerja Siswa Berbasis Pendekatan Kontekstual pada Materi Lingkaran Untuk Siswa SMP. Jurnal Review Pembelajaran Matematika, 3(1), 40-48. https://doi.org/10.15642/jrpm.2018.3.1.40-48

Gunhan, B. C. (2014). A case study on the investigation of reasoning skills in geometry. South African Journal of Education, 34(2), 1-19. https://doi.org/10.15700/201412071156

Haji, D. O. M. S., \& Herawaty, D. (2019). Pengembangan Bahan Ajar dengan Pendekatan Pembelajaran Santifik Berbantuan Geogebra Untuk Meningkatkan Kemampuan Spasial. Jurnal Pendidikan Matematika Raflesia, 4(2), 153-163.

Hanafi, M., Wulandari, K. N., \& Wulansari, R. (2017). Transformasi Geometri Rotasi Berbantuan Software Geogebra. Fibonacci Jurnal Pendidikan Matematika Dan MAtematika, 3(2), 93-102.

Handayani, S., \& Mandasari, N. (2018). Pengembangan Lembar Kerja Siswa (LKS) Berbasis Problem Based Learning untuk Meningkatkan Kemampuan Penalaran Matematika. Jurnal Pendidikan Matematika (JUDIKA EDUCATION), 1(2), 144-151. https://doi.org/10.31539/judika.v1i2.412

Haqq, A. A., Nur'azizah, \& Toheri. (2019). Reduksi Hambatan Belajar melalui Desain Didaktis Konsep Transformasi Geometri. SJME (Supremum Journal of Mathematics Education), 3(2), 117-127.

Herawati, L. (2017). Peningkatan kemampuan koneksi matematik peserta didik menggunakan model problem based learning (PBL) dengan berbantuan Software Geogebra. Jurnal Penelitian Pendidikan Dan Pengajaran Matematika, 
3(1), 39-44.

Hohenwarter, M., Hohenwarter, J., Kreis, Y., \& Lavicza, Z. (2008). Teaching and learning calculus with free dynamic mathematics software GeoGebra. 11th International Congress on Mathematical Education. Monterrey, Nuevo Leon, Mexico.

Mawarsari, V. D., \& Purnomo, E. A. (2017). Pemanfaatan Software Geogebra Berbantuan E-Learning Dalam Pembelajaran Geometri. Jkpm, 4(2).

Nagy-Kondor, R. (2010). Spatial ability, descriptive geometry and dynamic geometry systems. Annales Mathematicae et Informaticae, 37, 199-210.

Nur'aini, I. L., Harahap, E., Badruzzaman, F. H., \& Darmawan, D. (2017). Pembelajaran Matematika Geometri Secara Realistis Dengan GeoGebra. Matematika, 16(2), 1-6. https://doi.org/10.29313/jmtm.v16i2.3900

Octariani, D., \& Rambe, I. H. (2018). Pengembangan Bahan Ajar Berbasis Project Based Learning Berbantuan Software Geogebra. MES: Journal of Mathematics Education and Science, 4(1), 16-21. https://doi.org/10.30743/mes.v4i1.864

Prabawati, M. N., Herman, T., \& Turmudi, T. (2019). Pengembangan Lembar Kerja Siswa Berbasis Masalah dengan Strategi Heuristic untuk Meningkatkan Kemampuan Literasi Matematis. Mosharafa: Jurnal Pendidikan Matematika, 8(1), 37-48.

Rohaeti, E. E., \& Bernard, M. (2018). the Students' Mathematical Understanding Ability Through Scientific-Assisted Approach of Geogebra Software. Infinity Journal, 7(2), 165. https://doi.org/10.22460/infinity.v7i2.p165-172

Sangwin, C. (2007). A brief review of GeoGebra: dynamic mathematics. MSOR Connections, 7(2), 36-38. https://doi.org/10.11120/msor.2007.07020036

Septina, N., Farida, F., \& Komarudin, K. (2018). Pengembangan Lembar Kerja Siswa Dengan Pendekatan Saintifik Berbasis Kemampuan Pemecahan Masalah. Jurnal Tatsqif, 16(2), 160-171. https://doi.org/10.20414/jtq.v16i2.200

Supriyadi, E. W. A., Suharto, S., \& Hobri. (2017). Analisis Kemampuan Koneksi Matematis Berdasarkan NCTM (National Council of Teachers of Mathematics) Siswa SMK Kelas XI Jurusan Multimedia pada Pokok Bahasan Hubungan Antar Garis. Kadikma, 8(1), 128-136. 